\title{
A Simple Method of Converting Rangeland Drills to Experi- mental Plot Seeders
}

\author{
KENNETH P. VOGEL
}

Highlight: Rangeland drills can be converted to experimental plot drills by mounting a cone seeder and a spinner divider over the seed box. The cone seeder feeds a uniform amount of seed over the length of a plot and the spinner divider splits the seed into fractions with each fraction going to a different planting unit of the drill. Only one packet containing the amount of pure live seed to plant a plot is needed. Converted drills are selfcleaning. Numerous forage species can be seeded in contiguous plots without modifying or recalibrating the planter.

Seeding rangelands and other sites to improved grasses and legumes often requires drills designed specifically for that purpose. Rangeland drills have been developed that are capable of seeding light, chaffy seeds into poorly prepared seedbeds on rugged terrain. New power tillage drills are capable of seeding directly into swards without any seedbed preparation other than the use of herbicides to kill existing vegetation (Smith and Calvert 1976). This paper describes a simple method of converting conventional drills into plot seeders without extensive modification using commercially available equipment.

Using unmodified rangeland drills for seeding experimental plots presents many problems. Large quantities of seed are needed to fill seed boxes to the level necessary to obtain uniform rates of seeding. Experimental varieties are usually available only in small quantities. Increasing seed lots to the quantities needed can delay initial evaluation several years. Unmodified drills must be emptied and cleaned between contiguous plots. Extensive recalibration of drills is often required because several species and mixtures may be in the same experiment. Ideally, the drill should be recalibrated for seed lots differing in percentage of pure live seed.

The author is research agronomist, Science and Education Administration, U.S. Department of Agriculture, $331 \mathrm{Keim}$ Hall, East Campus, University of Nebraska, Lincoln 68583. The article is a contribution of the Sci. and Ed. Admin., U.S. Dep. Agr. and the Department of Agronomy, University of Nebraska-Lincoln. Published as Paper Number 5343, Journal Series, Nebraska Agricultural Experiment Station.

Manuscript received August 22, 1977.
Numerous plot drills have been developed for seeding agronomic trials. Most are unsuitable for use in rangeland trials because they cannot seed chaffy grass seed or they cannot be used in rangeland seedbeds. Many agronomic plot drills have desirable features that can be used on rangeland drills.

The three main components of a plot drill are the seed feeding mechanism, seed dividing mechanism, and the seeding mechanism. Most rangeland drills have suitable seeding mechanisms. Only the seed feeding and seed dividing mechanisms need to be changed to convert them into plot seeders.

Feeding mechanisms are used to feed a uniform amount of seed over the entire length of a plot. Feeding mechanisms most commonly used on plot drills are slotted, revolving belts (Frey and Downs 1950; Patterson, et al. 1957) and rotating cones (Barker, et al. 1976; Beard and Freeman 1960; Berg 1958; Marshall 1972; фyjord 1963; and Schmidt 1971). Belts or cones are gear driven by planter or packer wheels and are geared so that one complete revolution of a cone or one-half revolution of a belt occurs when the planter moves the length of a plot. As the belt moves forward and the cone rotates, seed is dumped into a seed divider or directly into seeding tubes. At the end of a plot, the self-cleaning belts or cones are empty and can be filled with seed for planting the next plot. Only the amount of pure live seed necessary to seed a plot is placed on a belt or in a cone, which simplifies calibration and keeps to a minimum the amount of seed needed. Cones are more compact and easier to feed than belts and it is easier to shield them from wind.

Seed dividers are used to split the seed into fractions with each fraction going to a separate planting unit, i.e., disk openers, hoes, or shoes. They make it possible to seed one plot with one packet of seed. This greatly reduces the labor involved in seed packaging in comparison to drills (Beard and Freeman 1960; and Berg 1958) that have no dividers but use a separate cone for each planting unit. Agronomic plot drills use various methods of dividing seed 


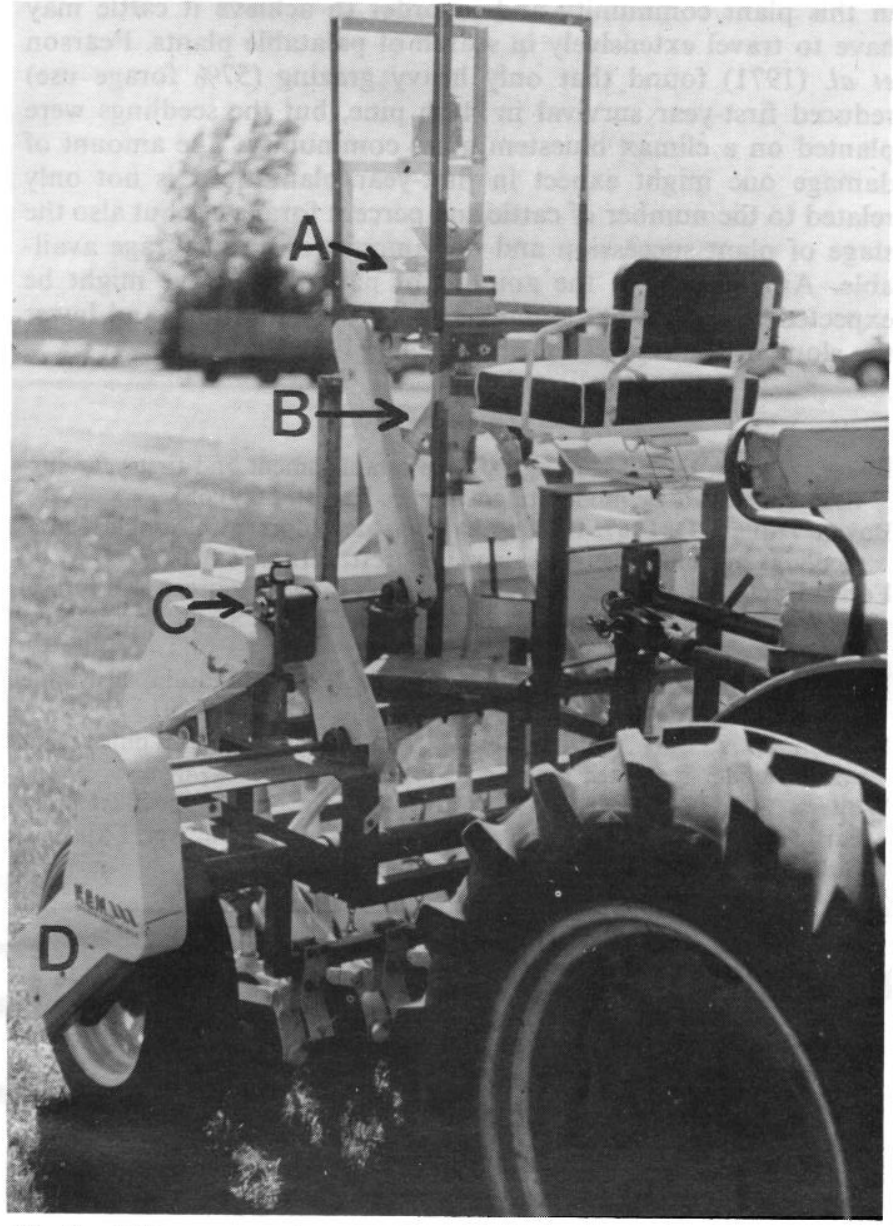

Fig. 1. Oblique view of grass plot drill showing the cone $(A)$, the divider (B), Zero-Max unit (C), and the gear drive from the right wheel (D).

lots including baffle sets (Frey and Downs 1950; and Patterson et al. 1957), Boerner dividers (Clark and Fehr 1973), multiple outlet cones (Marshall 1972; and Schmidt 1971) and spinner dividers (Barker et al. 1976; and $\phi$ yjord 1963). Baffles and Boerner dividers are easily plugged and hence are not usable with chaffy grass seed. Spinner dividers can be used with all types of seed including chaffy grass seed. Chaffy grasses can be seeded with some multiple outlet cones (Schmidt 1971) but more than one cone is needed.

$\phi y j o r d$ (1963) developed and described the spinner divider, which he called a distributor. The operating principle of Oyjord's seed divider is simple. A tightly fitting spinning device is located inside a housing that is vented only with seed outlet tubes. The spinner can be a finned dome or a partially finned dome. As seed is dumped on top of the spinner, its rapid rotation throws the seed into the seed tube outlets. The rotation of the spinner effectively divides the seed sample. Spinners may be mechanically or electrically powered. Interchangeable distributors with two to ten seed tube outlets can be used for different numbers of seeding units.

A K. E. M. Corp. ${ }^{1}$ plot grain drill was modified into a cone seeder with a spinner divider by K. E. M. Corp. according to my specifications. The same procedure could be used to convert rangeland drills to plot seeders using commercially available cones and distributors. A K. E. M. cone seeder and spinner divider unit was mounted over the seed box of the planter (Figs. 1 and 2). The cone is driven by one of the planter wheels using a gear drive assembly. The gear drive is directed through a Zero-Max ${ }^{1}$ unit, which makes it possible to vary plot length from 1.2 to $15.2 \mathrm{~m}$ by

Mention of a trademark, proprietary product or vendor, does not constitute a guarantee or warranty of the product by the U.S. Department of Agriculture and does not imply its approval to the exclusion of other products or vendors that may also be suitable.

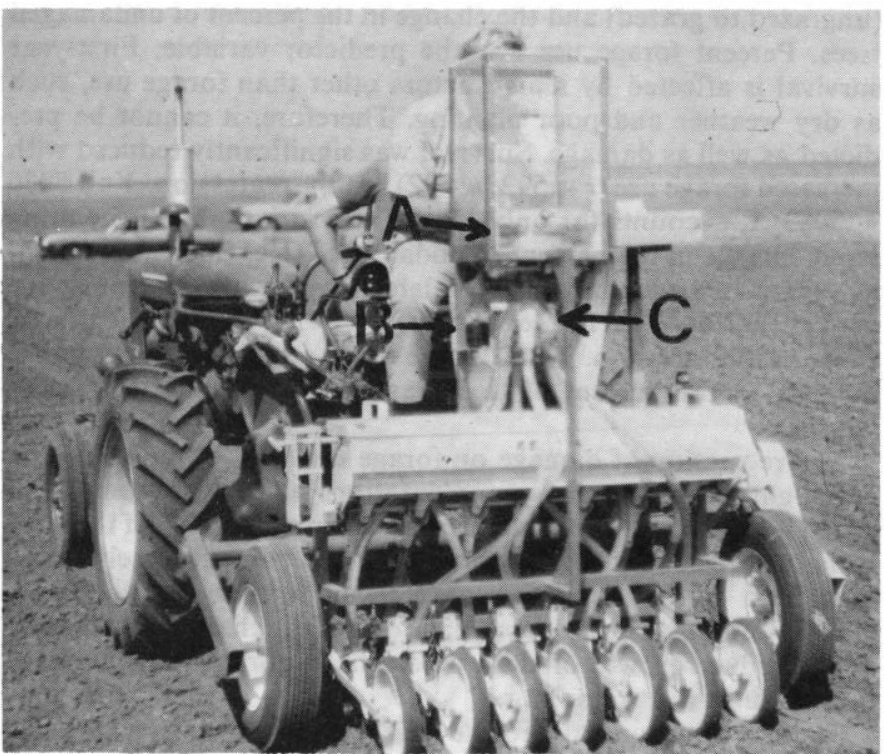

Fig. 2. Rear view of the grass plot drill in operation showing cone $(A)$, electric motor for the spinner (B) and the divider $(C)$.

cranking new settings into the unit, which has a digital display. The drill has seven disk openers spaced $18 \mathrm{~cm}$ apart. Planting depth is regulated by adjusting the position of the planter wheels using a hand crank.

The cone is $20.3 \mathrm{~cm}$ in diameter and has 20 cells. The cone rotates on a plate that has an opening equal in size to a cone cell. As the cone rotates, seed drops through the cone plate and into the seed divider via a connecting tube. A seed cup is centered over the cone apex and fits into a sleeve in which it can slide up or down. Seed is poured into the cup and leveled. Seed is then dumped into the cone by raising the cup. The seed cup can be raised manually or by using an electromagnetic lifting device. A plexiglass box was built around the cone for protection from the wind. The bottom half of the side facing the operator was left open.

A small electric motor (Fig. 2) is used for rotating the spinner in the divider. The electric motor is powered by the tractor's battery. The operator can turn the motor off using a toggle switch mounted on the cone. Clear plastic seed tubes lead from the distributor outlets to the planting units. Distributors with four and seven outlets are shown in Figures 1 and 2, respectively.

Figure 2 shows the plot drill in use. Normal plot size is $4.5 \mathrm{~m}$ long $\times 1.25 \mathrm{~m}$ wide. Contiguous plots are separated by a $1.5-\mathrm{m}$ alley. The cone is set to make one revolution when the drill moves $6 \mathrm{~m}$. Seeding begins in the middle of an alley. The drill is empty and clean in the middle of the next alley and the cone is filled with seed and the process is repeated. The tractor wheels are used to mark the alleys.

I have seeded 14 species of grass with this drill including smooth bromebrass, Bromus inermis Leyss.; four species of wheatgrass, Agropyron; creeping Foxtail, Alopecurus arundinaceus Poir.; switchgrass, Panicum virgatum L.; and sand lovegrass, Eragrostis trichodes (Nutt.) Wood. Extremely small seeds such as sand lovegrass can slip under the edges of the cone partitions as the cone rotates. This results in erratic feeding of seed into the seed divider and incomplete cleaning of the cone. Flat seeds such as smooth bromegrass sometimes slip under the edges of the cone partitions, causing the cone to jam. Both problems are solved by dumping approximately $20 \mathrm{ml}$ of fine vermiculite into the cone before the seed is added. The vermiculite prevents seed from slipping under the cone partitions and gently sweeps the seed along. Vermiculite works so well that it is now used routinely with seed of all grass species.

Barker et al. (1976) has seeded 44 forage species with a cone seeder and a spinner divider, including little bluestem, Andropogon scoparius Michx. They were able to plant this extremely 
chaffy seed by adding granite grit to the seed as described by Schmidt (1971). The K.E.M. 20-cm cone does not have the capacity to handle enough seed of unprocessed little bluestem and big bluesten, Andropogon gerardi Vitman, to plant a $4.5-\mathrm{m}$ plot. Excessive amount of seed in the cone causes plugging of the seed tubes. The granite grit used by Schmidt (1971) and Barker et al. (1976) is very abrasive and damages the brass plate of the cone.

Chaff and seed appendages of little and big bluestem and other chaffy grasses can be removed by using seed processing methods described by Harland and Ahring (1960); Schwendiman et al. (1940); and Weber (1939). Processed seed can be easily used in the cone seeder. However, all orifices in the planting system should be at least $2.5 \mathrm{~cm}$ in diameter.

A cone and spinner divider could be mounted on any rangeland drill to be converted into a plot seeder. The drill described in this paper differs from the one described by Barker et al. (1976) in that a much simpler method of converting the drill and shielding the cone was used. Cones and spinner dividers are available from several firms.

\section{Literature Cited}

Barker, R. E., J. J. Bond, and L. C. Zachmeier. 1976. Equipment for seeding experimental plots of small grains, grasses, and legumes. Agron. J.
68:141-142.

Beard, B. H., and J. K. Freeman. 1960. A cone-type nursery planter. Agron. J. 52:362-363.

Berg, M. A. 1958. A field plot seeder. Agron. J. 50:713-714.

Clark, R. C., and W. R. Fehr. 1973. Seed divider for plot planters. Crop Sci. 13:763-764.

Frey, K. J., and E. F. Downs. 1950. A multiple-row nursery seeder. Agron. J. 42:413-414.

Harlan, J. R., and R. M. Ahring. 1960. A suggested method for determining purity of certain chaffy-seeded grasses. Agron. J. 52:223-226.

Marshall, H. G. 1972. A single cone multiple-row plot seeder. Crop Sci. 12:871-872.

$\varnothing$ yjord, E. 1963. A universal experimental seed drill. J. Agr. Eng. Res. 8:85-87.

Patterson, F. L., J. F. Schafter, and D. E. Burrough. 1957. Small grain nursery seeder, marker, and cultivator. Agron J. 49:461-463.

Schmidt, A. R. 1971. Plot seeding of light chaffy grass seed. Agron. J. 63:332-333

Schwendiman, John L., Roland F. Sackman, and A. L. Hafenrichter. 1940. Processing seed of grasses and other plants to remove awns and appendages. U.S. Dep. Agr. Circ. No. 558.

Smith, A. E., and G. V. Calvert. 1976. Modification of a grassland drill for sward interseeding. Agron. J. 68:985-986.

Weber, G. L. 1939. A method of preparing some native grass seeds for handling and seeding. J. Amer. Soc. Agron. 31:729-733. 